\title{
Prophylactic blood transfusion prior to elective invasive procedures
}

\author{
Marcelo Antônio Oliveira Santos-Veloso 1,2,3* ๑), \\ Gustavo Lago Oliveira de Souza1,4 ${ }^{1}$, Alessandra Ferraz de Sá1,5
}

\section{INTRODUCTION}

In Brazil, approximately 3.3 million blood transfusions are performed annually, of which $62.4 \%$ correspond to packed red blood cells (PRBCs), 17\% to platelet concentrates (PC), and $13 \%$ to fresh frozen plasma ${ }^{1}$. The use of blood products (BPs) is one of the most common interventions in clinical practice and can save lives when indicated.

In both developed and developing countries, inappropriate prescription of blood components occurs in up to $36 \%$ of cases $^{2}$. The rational prescription of transfusion therapies is essential due to limited resources and growing demand ${ }^{3}$. Moreover, several studies have shown that aggressive correction of anemia, thrombocytopenia, and coagulopathies does not necessarily result in better clinical outcomes ${ }^{4}$.

These factors show the importance of individually tailoring the indications and establishing evidence-based transfusion programs 5 . However, several international medical guidelines still recommend the prescription of BP based on low-quality studies or expert opinion ${ }^{6,7}$.

In this study, a narrative review of the literature was conducted regarding the evidence for the prescription of BP prophylaxis for elective invasive procedures in clinically stable patients with anemia, thrombocytopenia, or coagulopathies.

The included studies were classified according to the quality of the scientific evidence following the 2011 Oxford Center for Evidence-Based Medicine recommendations (Table 1) . $^{8}$.

\section{CENTRAL VENOUS CATHETER PUNCTURE-RELATED TRANSFUSION}

Evidence regarding the use of blood components prior to central venous catheter (CVC) puncture in patients with blood dyscrasias is scarce. Most international guidelines recommend performing thrombocytopenia and international normalized ratio (INR) correction before the puncture but at variable cutoff points ${ }^{7,9}$. Nevertheless, classic coagulogram parameters (i.e., prothrombin time, INR, and platelet count) have been poor predictors of bleeding-related complications after CVC puncture ${ }^{10}$.

A meta-analysis including 4,387 CVC insertions revealed a $5.1 \%$ risk of bleeding complications. The efficacy of blood transfusions in preventing these complications could not be determined due to the high heterogeneity and low methodological quality of the studies ${ }^{11}$.

\section{ESOPHAGOGASTRODUODENOSCOPY}

In clinical practice, esophagogastroduodenoscopy (EGD) plays an essential role in the diagnosis and treatment of severe digestive bleeding. This is a heterogeneous clinical context, which may involve patients with or without hemodynamic instability, coagulation disorders, and/or thrombocytopenia.

Based on low-quality evidence, the American Society for Gastrointestinal Endoscopy recommends a minimum value of

\footnotetext{
${ }^{1}$ Hospital dos Servidores do Estado de Pernambuco, Serviço de Clínica Médica - Recife (PE), Brazil.

${ }^{2}$ Universidade Federal de Pernambuco, Centro de Biociências, Programa de Pós-Graduação em Inovação Terapêutica - Recife (PE), Brazil. ${ }^{3}$ Centro Universitário Maurício de Nassau, Curso de Medicina, Departamento de Saúde - Recife (PE), Brazil.

${ }^{4}$ Hospital Barão de Lucena, Serviço de Urgência e Emergência - Recife (PE), Brazil.

${ }^{5}$ Fundação de Hematologia e Hemoterapia de Pernambuco, Serviço de Hematologia - Recife (PE), Brazil.

${ }^{\star}$ Corresponding author: marcelosantos.med@gmail.com

Conflicts of interest: the authors declare there are no conflicts of interest.

Funding: This work was funded by the Secretaria de Saúde do Estado de Pernambuco as a part of the Medical Residency Program Grant. Received on June 08, 2021. Accepted on June 16, 2021.
} 
Table 1. Oxford Centre for Evidence-Based Medicine levels of evidence according to the study design.

\begin{tabular}{|c|c|c|c|c|c|}
\hline $\begin{array}{l}\text { Grades of } \\
\text { recommendation }\end{array}$ & $\begin{array}{l}\text { Level of } \\
\text { evidence }\end{array}$ & $\begin{array}{l}\text { Therapy, } \\
\text { prevention, } \\
\text { and etiology }\end{array}$ & Prognosis & Diagnosis & $\begin{array}{l}\text { Differential } \\
\text { diagnosis or } \\
\text { prevalence }\end{array}$ \\
\hline \multirow{3}{*}{ A } & $1 \mathrm{~A}$ & $\begin{array}{c}\text { Systematic review } \\
\text { of RCTs }\end{array}$ & $\begin{array}{l}\text { Systematic review } \\
\text { of cohort studies. } \\
\text { CDR validated } \\
\text { in different } \\
\text { populations }\end{array}$ & $\begin{array}{l}\text { Systematic review of } \\
\text { Level } 1 \text { diagnostic } \\
\text { studies. CDR with } 1 \mathrm{~b} \\
\text { studies from different } \\
\text { clinical centers }\end{array}$ & $\begin{array}{l}\text { Systematic } \\
\text { reviews of cohort } \\
\text { studies (current } \\
\text { or prospective) }\end{array}$ \\
\hline & $1 \mathrm{~B}$ & $\begin{array}{l}\text { RCT with narrow } \\
\text { confidence interval }\end{array}$ & $\begin{array}{l}\text { Cohort study with } \\
<20 \% \text { loss. CDR } \\
\text { validated in a } \\
\text { single population }\end{array}$ & $\begin{array}{l}\text { Validating cohort } \\
\text { study with good } \\
\text { reference standards. } \\
\text { CDR tested within } \\
\text { one clinical center }\end{array}$ & $\begin{array}{l}\text { Prospective cohort } \\
\text { study with good } \\
\text { follow-up }\end{array}$ \\
\hline & $1 \mathrm{C}$ & $\begin{array}{l}\text { Results of all or } \\
\text { none studies }\end{array}$ & $\begin{array}{l}\text { All or none } \\
\text { case-series }\end{array}$ & $\begin{array}{l}\text { Sensitivity and } \\
\text { specificity close } \\
\text { to } 100 \%\end{array}$ & $\begin{array}{l}\text { All or none } \\
\text { case-series }\end{array}$ \\
\hline \multirow{5}{*}{ B } & $2 \mathrm{~A}$ & $\begin{array}{l}\text { Systematic review } \\
\text { of cohort studies }\end{array}$ & $\begin{array}{l}\text { Systematic review } \\
\text { of retrospective } \\
\text { cohort studies }\end{array}$ & $\begin{array}{l}\text { Systematic review } \\
\text { of Level >2 } \\
\text { diagnostic studies }\end{array}$ & $\begin{array}{l}\text { Systematic review } \\
\text { of } 2 \mathrm{~b} \text { and better } \\
\text { differential } \\
\text { diagnosis studies }\end{array}$ \\
\hline & $2 B$ & $\begin{array}{l}\text { Cohort study or } \\
\text { low-quality RCT }\end{array}$ & $\begin{array}{l}\text { Retrospective } \\
\text { cohort study, } \\
\text { CDR validated } \\
\text { on split-sample }\end{array}$ & $\begin{array}{l}\text { Exploratory cohort } \\
\text { study with good } \\
\text { reference standards. } \\
\text { CDR validated only } \\
\text { on split samples } \\
\text { or databases }\end{array}$ & $\begin{array}{l}\text { Retrospective } \\
\text { cohort study or } \\
\text { poor follow-up }\end{array}$ \\
\hline & $2 C$ & $\begin{array}{l}\text { "Outcomes" research. } \\
\text { Ecological studies. }\end{array}$ & $\begin{array}{l}\text { "Outcomes" } \\
\text { research }\end{array}$ & - & Ecological studies \\
\hline & $3 \mathrm{~A}$ & $\begin{array}{l}\text { Systematic review of } \\
\text { case-control studies }\end{array}$ & - & $\begin{array}{l}\text { Systematic review of } \\
3 \mathrm{~b} \text { and better studies }\end{array}$ & $\begin{array}{l}\text { Systematic } \\
\text { review of } 3 b \text { and } \\
\text { better studies }\end{array}$ \\
\hline & $3 B$ & Case-control study & - & $\begin{array}{l}\text { Nonconsecutive } \\
\text { study or without } \\
\text { consistently applied } \\
\text { reference standards }\end{array}$ & $\begin{array}{l}\text { Nonconsecutive } \\
\text { cohort study, } \\
\text { or very limited } \\
\text { population }\end{array}$ \\
\hline C & 4 & $\begin{array}{l}\text { Case-series, poor } \\
\text { quality cohort, and } \\
\text { case-control studies }\end{array}$ & $\begin{array}{l}\text { Case-series, poor } \\
\text { quality prospective } \\
\text { cohort studies }\end{array}$ & $\begin{array}{l}\text { Case-control } \\
\text { study, poor or } \\
\text { nonindependent } \\
\text { reference standard }\end{array}$ & $\begin{array}{l}\text { Case-series or } \\
\text { superseded } \\
\text { reference standards }\end{array}$ \\
\hline
\end{tabular}

D

Expert opinion without explicit critical appraisal or based on basic science (physiology, bench research)

RCT: randomized clinical trial; CDR: clinical decision rule.

$20^{\prime} 10^{3}$ platelets $/ \mathrm{mm}^{3}$ to perform EGD in patients at low risk of bleeding and $50^{\prime} 10^{3}$ platelets $/ \mathrm{mm}^{3}$ in those at high risk ${ }^{12}$. Meanwhile, the British guidelines recommend performing EGD with platelet reserve in patients with less than $50-80^{\prime} 10^{3}$ platelets $/ \mathrm{mm}^{313}$. However, two systematic reviews demonstrated that the existing evidence is insufficient to establish a cutoff point for performing EGD in thrombocytopenic patients and that the current recommendations are based on expert opinion ${ }^{14,15}$.

Some randomized controlled trials (RCTs) evaluated the transfusion of PRBCs in patients with upper gastrointestinal 
bleeding and showed lower mortality associated with the use of restrictive strategies (transfusion to maintain $\mathrm{Hb} 7-8 \mathrm{~g} / \mathrm{dL}$ ) ${ }^{16}$. The European Society of Gastrointestinal Endoscopy guideline corroborates this strategy recommending $\mathrm{Hb}$ values between 7 and $9 \mathrm{~g} / \mathrm{dL}^{17}$.

As for coagulopathy, no study demonstrated the risk of a new bleeding event in patients with elevated INR ( 2.5 or higher) or the use of anticoagulants ${ }^{18}$. Despite this, a cohort indicates that performing early EGD $(<24 \mathrm{~h})$ is safe in patients after partial INR correction, with a similar risk to patients with no coagulopathies ${ }^{19}$. The International Consensus Group recommends the correction of coagulopathies in advance due to the benefits of early EGD and low evidence of complications, provided this does not delay endoscopy ${ }^{20}$.

\section{BRONCHOSCOPY}

Bronchoscopy is a well-established complementary method for investigating respiratory system pathologies, including bronchoalveolar lavage, lung parenchyma biopsy, and therapeutic procedures. The incidence of hemorrhagic complications after bronchoscopy is approximately $0.44 \%{ }^{21}$.

According to the latest guideline of the American Association of Blood Banks, bronchoscopy can be safely performed in patients with a platelet count $\geq 20^{\prime} 10^{3} / \mathrm{mm}^{3}$. This recommendation is mainly based on observational studies with limited sample sizes ${ }^{22}$. Despite this, a recent cohort study observed a low rate of bleeding complications in 1,711 cancer patients with thrombocytopenia, including those with a platelet count $<20^{\prime} 10^{3} / \mathrm{mm}^{3}$. Approximately, $45 \%$ of the patients with $10-20^{\prime} 10^{3}$ platelets $/ \mathrm{mm}^{3}$ did not receive prophylactic PC transfusion, and even so, there was no significant difference in bleeding complications ${ }^{23}$. In the case of levels $<10^{\prime} 10^{3}$ platelets $/ \mathrm{mm}^{3}$, PC transfusion before the procedure is plausible due to the high risk of spontaneous bleeding ${ }^{10}$.

\section{RENAL BIOPSY}

A major complication associated with renal biopsy is hemorrhagic bleeding, occurring in approximately $0.6-4.9 \%$ of cases $^{24}$. Some of the risk factors for post-biopsy bleeding are as follows: female sex, advanced age, elevated INR, hypertension, and increased baseline creatinine levels ${ }^{25,26}$. The use of ultrasound in clinical practice allowed the use of open biopsies in some specific cases, as well as CT-, laparoscopic-, or transjugular-guided biopsies.

The use of BPs, especially PRBCs, tends to be more strongly influenced by pre-procedure baseline hemoglobin values rather than by the decrease in hemoglobin levels during the biopsy, the presence of perinephric hematoma, or the need for post-procedure surgical approach ${ }^{27}$. In a large meta-analysis of randomized clinical trials, Salpeter et al. do not recommend routine blood transfusion after renal biopsy because of increased mortality, higher incidence of acute myocardial infarction, pulmonary edema, and bacterial infection $s^{28}$. However, the cutoff point for blood transfusion in these patients is controversial, and there are no major RCTs on the use of blood concentrates before or after this procedure ${ }^{27}$.

Regarding platelet transfusion, the thrombocyte level decrease is associated with the development of symptomatic hematoma ${ }^{29}$. In a retrospective study, Simard-Meilleur et al. demonstrated that the risk of this complication is inversely proportional to the serum platelet level, being $11 \%$ in patients with $>200^{\prime} 10^{3}$ platelets $/ \mathrm{mm}^{3}$ and $40 \%$ in those with levels $<100^{\prime} 10^{3}$ platelets $/ \mathrm{mm}^{3} 29$.

\section{LIVER BIOPSY}

The most severe complications of liver biopsies are intraperitoneal hemorrhage, hemobilia, and hematoma formation. The risk of clinically relevant bleeding complications that result in hemodynamic compromise or require some form of intervention ranges from 0.01 to $0.5 \%{ }^{30,31}$.

Both organ dysfunction and hepatosplenomegaly as a result of chronic liver diseases may result in blood dyscrasias, either by INR change or by platelet destruction and dysfunction. Thus, the American Association for the Study of Liver Diseases recommends the correction of thrombocytopenia to serum levels below $50-60^{\prime} 10^{3}$ platelets $/ \mathrm{mm}^{3}{ }^{32}$. Regarding INR, the Society of Interventional Radiology defines its cutoff point for performing biopsy as an INR $\leq 1.5-1.8$ and $<2.5$ for the general population and for patients with chronic liver disease (CLD), respectively ${ }^{33}$.

In the largest RCT evaluating the performance of percutaneous liver biopsy in patients with advanced CLD, the HALT-C indicated an increased risk of post-procedure bleeding in patients with platelet counts $\leq 60^{\prime} 10^{3} / \mathrm{mm}^{3}(5.3 \%$ versus $0.4 \% ; \mathrm{p}<0.001)$ and INR $\geq 1.3^{34}$. However, this study excluded thrombocytopenia $<50^{\prime} 10^{3} / \mathrm{mm}^{3}$, and no patients with INR $>1.5$ experienced bleeding events.

\section{FINAL ANALYSIS}

This study found few and sometimes contradictory data on the indication of blood component transfusion before invasive procedures. Most published studies correspond to observational studies with heterogeneous results and several methodological limitations. 
This study found a significant inconsistency in recommendations between the guidelines evaluated and also regarding the evidence available in the literature, indicating that such recommendations are based on expert opinion.
Table 2 shows a synthesis of the main studies, their recommendations, recommended cutoff values for platelet count and INR, and data on the quality of evidence. Figure 1 presents the final recommendations based on these results.

Table 2. Synthesis of evidence levels and recommendations for studies evaluating prophylactic blood transfusion and/or bleeding risk related to elective invasive procedures.

\begin{tabular}{|c|c|c|c|c|c|c|}
\hline Procedure & $\begin{array}{l}\text { Platelet } \\
\text { count }^{\pi}\end{array}$ & INR & Recommendation* & $\mathrm{LOE}^{¥}$ & Comments & References \\
\hline \multirow{4}{*}{$\begin{array}{l}\text { CVC } \\
\text { puncture }\end{array}$} & - & - & $\begin{array}{c}\text { Benefit is unclear. Prophylactic } \\
\text { transfusion or if bleeding after } \\
\text { the procedure seems equally } \\
\text { acceptable alternatives }\end{array}$ & $2 a$ & $\begin{array}{l}\text { Systematic review of } 13 \\
\text { observational studies. } \\
\text { High heterogeneity }\end{array}$ & $\begin{array}{l}\text { Cabrini } \\
\text { L. et al. } \\
2017^{11}\end{array}$ \\
\hline & $20^{\prime} 10^{3}$ & 3.0 & $\begin{array}{l}\text { The benefit of prophylactic } \\
\text { reversion of coagulopathies or } \\
\text { thrombocytopenia correction } \\
\text { is unclear }\end{array}$ & $2 a$ & $\begin{array}{c}\text { Systematic review: } 01 \text { RCT e } \\
21 \text { observational study. High } \\
\text { heterogeneity. Studies of poor to } \\
\text { moderate quality }\end{array}$ & $\begin{array}{l}\text { van de } \\
\text { Weerdt } \\
\text { E.K. et al. } \\
2017^{35}\end{array}$ \\
\hline & $30^{\prime} 10^{3}$ & $1.5-3.0$ & $\begin{array}{c}\text { Prophylactic reversion of } \\
\text { coagulopathies with FFP could } \\
\text { not be evaluated }\end{array}$ & $2 b$ & $\begin{array}{c}\text { Open-label RCT, concealed, } \\
4 \text { centers, with } 81 \text { patients. } \\
\text { Compared FFP versus placebo. } \\
\text { Truncated due to slow recruitment }\end{array}$ & $\begin{array}{l}\text { Müller } \\
\text { M.C. et al. } \\
2015^{36}\end{array}$ \\
\hline & $50^{\prime} 10^{3}$ & 1.5 & $\begin{array}{l}\text { Thrombocytopenia or } \\
\text { increased INR were not } \\
\text { related to the risk of bleeding. } \\
\text { Prophylactic correction is not } \\
\text { recommended }\end{array}$ & $2 c$ & $\begin{array}{c}\text { Open-label not randomized trial } \\
\text { with } 196 \text { subjects in } 02 \text { intensive } \\
\text { care units }\end{array}$ & $\begin{array}{l}\text { Weigand } \\
\text { K. et al. } \\
2009^{37}\end{array}$ \\
\hline \multirow{3}{*}{ EGD } & $50^{\prime} 10^{3}$ & - & $\begin{array}{l}\text { The platelet count cutoff of } \\
50^{\prime} 10^{3} \text { is safe to perform } \\
\text { EGD. In patients in which this } \\
\text { value is difficult to reach, a } \\
\text { cutoff of } 20^{\prime} 10^{3} \text { is reasonable }\end{array}$ & 4 & $\begin{array}{l}\text { Retrospective study in one } \\
\text { site with } 588 \text { oncology } \\
\text { patients, which of } 20 \% \text { had a } \\
\text { performance status of } 3 \text { or } 4\end{array}$ & $\begin{array}{l}\text { Abu-Sbeih } \\
\text { H. et al. } \\
2019^{38}\end{array}$ \\
\hline & $20-50^{\prime} 10^{3}$ & - & $\begin{array}{l}\text { Safe procedure in } \\
\text { thrombocytopenic patients. } \\
\text { Low risk of bleeding, no severe } \\
\text { or fatal bleeding. Prophylactic } \\
\text { platelet transfusion should be } \\
\text { individualized }\end{array}$ & $2 b$ & $\begin{array}{c}\text { Systematic review of } 11 \\
\text { observational studies. High } \\
\text { heterogeneity. High proportion } \\
\text { of oncology patients }\end{array}$ & $\begin{array}{l}\text { Tong M.C. } \\
\text { et al. } \\
2015^{15}\end{array}$ \\
\hline & $50^{\prime} 10^{3}$ & - & $\begin{array}{l}\text { The study results demonstrate } \\
\text { a trend to no difference in risks } \\
\text { for a platelet count } 10-20^{\prime} 10^{3} \text {. } \\
\text { Conversely, the authors suggest } \\
\text { transfusion for a platelet count } \\
<50^{\prime} 10^{3} \text { based on guideline } \\
\text { recommendations }\end{array}$ & $2 a$ & $\begin{array}{l}\text { Systematic review of } 20 \text { studies: } \\
4 \mathrm{RCT} \text { and } 16 \text { observational } \\
\text { studies. High proportion of } \\
\text { oncology patients }\end{array}$ & $\begin{array}{l}\text { Razzaghi A. } \\
\text { and Barkun } \\
\text { A.N. } 2012^{14}\end{array}$ \\
\hline Bronchoscopy & $10^{\prime} 10^{3}$ & - & $\begin{array}{l}\text { Prophylactic transfusion is } \\
\text { not routinely recommended. } \\
\text { In patients whose platelet } \\
\text { count is }<10^{\prime} 10^{3} \text {, transfusion } \\
\text { seems reasonable due to } \\
\text { spontaneous bleeding risk }\end{array}$ & 4 & $\begin{array}{l}\text { Retrospective cohort in one } \\
\text { center with } 1,711 \text { patients. Only } \\
\text { pre-procedure platelet count was } \\
\text { analyzed. The authors could not } \\
\text { assure the absence of transfusion } \\
\text { during or after the procedures } \\
\text { in patients without evidence of } \\
\text { bleeding. Lung biopsy and BAL } \\
\text { were not assessed }\end{array}$ & $\begin{array}{l}\text { Faiz S.A. } \\
\text { et al. } \\
2019^{23}\end{array}$ \\
\hline
\end{tabular}


Table 2. Continuation.

\begin{tabular}{|c|c|c|c|c|c|c|}
\hline Procedure & $\begin{array}{c}\text { Platelet } \\
\text { count }^{\pi}\end{array}$ & INR & Recommendation* & $\operatorname{LOE}^{¥}$ & Comments & References \\
\hline \multirow[b]{2}{*}{ Bronchoscopy } & $30^{\prime} 10^{3}$ & - & $\begin{array}{l}\text { Prophylactic transfusion } \\
\text { recommended for a platelet } \\
\text { count }<30^{\prime} 10^{3} \text {, including } \\
\text { diagnosis purposes and BAL }\end{array}$ & 4 & $\begin{array}{c}\text { Retrospective cohort with } 150 \\
\text { patients. Prophylactic transfusion } \\
\text { was routinely performed. } \\
\text { Confusion bias. Biopsies not } \\
\text { assessed }\end{array}$ & $\begin{array}{l}\text { Nandagopal } \\
\text { L. et al. } \\
2016^{39}\end{array}$ \\
\hline & $20^{\prime} 10^{3}$ & - & $\begin{array}{l}\text { Bronchoscopy, including with } \\
\text { biopsy, is safely performed for } \\
\text { a platelet count } \geq 20^{\prime} 10^{3}\end{array}$ & $2 b$ & $\begin{array}{l}\text { Prospective observational study } \\
\text { with } 234 \text { patients, with a follow- } \\
\text { up of } 18 \text { months. Bronchoscopist } \\
\text { blinded. Thrombocytopenia } \\
<20^{\prime} 10^{3} \text { and INR }<1.3 \text { were } \\
\text { excluded. No occurrence of } \\
\text { bleeding or hemorrhage with } \\
\text { hemodynamic instabilities }\end{array}$ & $\begin{array}{l}\text { Carr I.M. } \\
\text { et al. } \\
2012^{40}\end{array}$ \\
\hline \multirow{3}{*}{ Renal biopsy } & - & - & $\begin{array}{l}\text { Lower pre-procedure } \mathrm{Hb} \text { is } \\
\text { associated with the higher } \\
\text { risk of transfusion after } \\
\text { biopsy despite the absence } \\
\text { of bleeding. Transfusion } \\
\text { prescription should be } \\
\text { individualized and consider } \\
\text { other risk factors instead of } \\
\text { only } \mathrm{Hb}\end{array}$ & $2 c$ & $\begin{array}{c}\text { Prospective study with } 910 \\
\text { adults which evaluated bleeding, } \\
\text { need for transfusion or death } 24 \\
\text { h after percutaneous biopsy }\end{array}$ & $\begin{array}{l}\text { Whittier } \\
\text { W.L. et al. } \\
2016^{27}\end{array}$ \\
\hline & - & - & $\begin{array}{l}\text { No recommendations. } \\
\text { Symptomatic hematoma was } \\
\text { associated with platelet count } \\
\text { and hemodialytic therapy }\end{array}$ & 4 & $\begin{array}{l}\text { Retrospective cohort study with } \\
287 \text { inpatients and outpatients. } \\
\text { No cutoff defined to guide } \\
\text { blood product transfusion. } \\
\text { Desmopressin was used in } 33 \% \\
\text { of patients }\end{array}$ & $\begin{array}{l}\text { Simard- } \\
\text { Meilleur } \\
\text { M.-C. et al. } \\
2014^{29}\end{array}$ \\
\hline & $\geq 50^{\prime} 10^{3}$ & 1.3 & $\begin{array}{c}\text { No recommendations. A } \\
\text { platelet count }<150^{\prime} 10^{3} \text { was } \\
\text { associated with increased risk } \\
\text { of hemorrhagic complications }\end{array}$ & $2 b$ & $\begin{array}{l}\text { Retrospective cohort study } \\
\text { with } 219 \text { patients with SLE in } \\
\text { a tertiary center. Desmopressin } \\
\text { use was excluded. Possibility of } \\
\text { information bias }\end{array}$ & $\begin{array}{l}\text { Chen } \\
\text { T. et al. } \\
2012^{41}\end{array}$ \\
\hline \multirow{3}{*}{ Liver biopsy } & $60^{\prime} 10^{3}$ & - & $\begin{array}{l}\text { Indication and benefit of } \\
\text { prophylactic blood product } \\
\text { transfusion prior to liver } \\
\text { biopsy in cirrhotic patients is } \\
\text { unclear }\end{array}$ & 5 & $\begin{array}{l}\text { Narrative review including } 15 \\
\text { studies with cirrhotic patients. } \\
\text { Heterogeneous studies. No } \\
\text { systematic approach or critical } \\
\text { information appraisal }\end{array}$ & $\begin{array}{l}\text { Alvaro } \\
\text { D. et al. } \\
2021^{30}\end{array}$ \\
\hline & $50^{\prime} 10^{3}$ & - & $\begin{array}{l}\text { Image-guided liver biopsies } \\
\text { are safe in patients with a } \\
\text { platelet count }>50^{\prime} 10^{3} / \mathrm{mm}^{3}\end{array}$ & $2 b$ & $\begin{array}{l}\text { Retrospective cohort study in } \\
\text { one center with 5,987 patients. } \\
\text { Information bias, events } \\
\text { identified from medical records. } \\
\text { Small number of events }\end{array}$ & $\begin{array}{l}\text { Boyum } \\
\text { J.H. et al. } \\
2016^{31}\end{array}$ \\
\hline & $60^{\prime} 10^{3}$ & 1.3 & $\begin{array}{c}\text { Percutaneous liver biopsy } \\
\text { should be avoided in patients } \\
\text { with a platelet count }<60^{\prime} 10^{3} \\
\text { due to increased risk of } \\
\text { bleeding }\end{array}$ & $2 b$ & $\begin{array}{c}\text { Multicentric open-label RCT } \\
\text { including } 2,749 \text { percutaneous } \\
\text { biopsies. No stratification to the } \\
\text { usage of an ultrasound device, } \\
\text { needle type, or the number of } \\
\text { attempts. Thrombocytopenia } \\
<50^{\prime} 10^{3} / \mathrm{mm}^{3} \text { was excluded and } \\
\text { no patients with INR }>1.5 \text { has bleed }\end{array}$ & $\begin{array}{l}\text { Seeff } \\
\text { L.B. et al. } \\
2010^{34}\end{array}$ \\
\hline
\end{tabular}

INR: international normalized ratio; LOE: level of evidence; CVC: central venous catheter; RCT: randomized clinical trial; FFP: fresh frozen plasma; EGD: esophagogastroduodenoscopy; BAL: bronchoalveolar lavage; $\mathrm{Hb}$ : hemoglobin; SLE: systemic lupus erythematosus.

*Recommendations of international guidelines were not listed in this table, since they are already mentioned in the text and mostly based on the opinion of experts (LOE 5).

nPlatelets $/ \mathrm{mm}^{3}$.

${ }^{¥}$ According to the Oxford Centre for Evidence-Based Medicine Classification. 


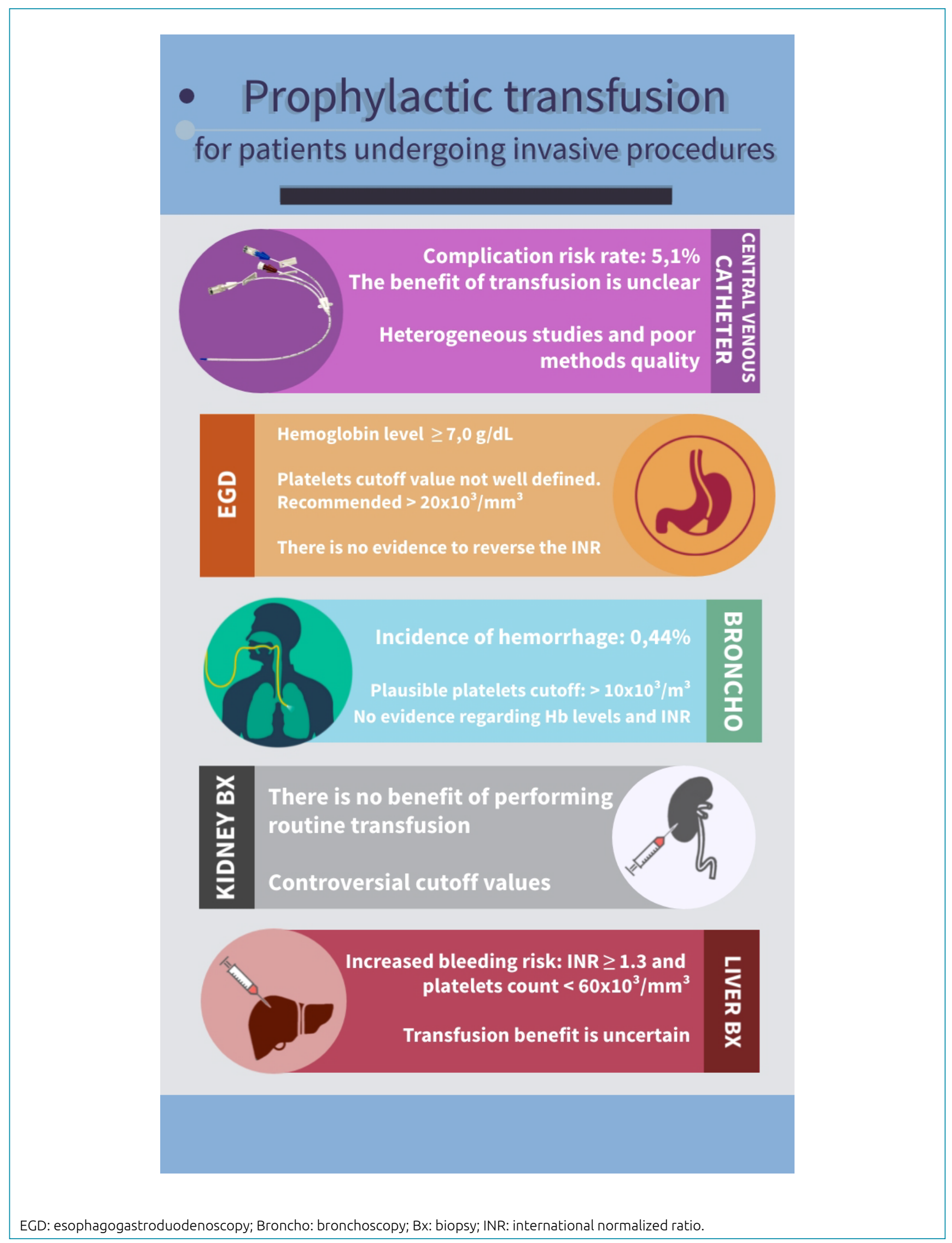

Figure 1. Recommendations for prophylactic blood transfusion prior to main elective invasive procedures. 


\section{CONCLUSIONS}

Few studies evaluated the indications of prophylactic blood transfusion for bleeding complications in patients with anemia, thrombocytopenia, or coagulopathies. The recommendations of international guidelines do not always reflect critical analyses of the available scientific evidence and should be reviewed and applied in clinical practice with caution.

\section{AUTHORS" CONTRIBUTIONS}

MAOSV: Conceptualization, Formal Analysis, Investigation, Methodology, Project Administration, Writing - Original Draft, and Writing - Review and Editing. GLOS: Conceptualization, Formal Analysis, Investigation, Methodology, and Writing ORIGINAL DRAFT. AFS: Supervision and Writing - Review $\&$ Editing.

\section{REFERENCES}

1. Silva DLQ, Brito KNP, Ferreira PHG, dos Santos APG. Caderno de informação: sangue e hemoderivados. Brasília: Ministério da Saúde; 2017

2. Sharif M, Saxena A, Singh S, Manchala S, Jafri N. Blood component transfusion in a tertiary care hospital. Indian J Pediatr. 2020;87(5):339-44. https://doi.org/10.1007/s12098020-03186-2

3. Mohammed AD, Ntambwe P, Crawford AM. Barriers to effective transfusion practices in limited-resource settings: from infrastructure to cultural beliefs. World J Surg. 2020;44(7):2094-9. https://doi.org/10.1007/s00268-02005461-x

4. Franchini M, Marano G, Mengoli C, Pupella S, Vaglio S, Muñoz M, et al. Red blood cell transfusion policy: a critical literature review. Blood Transfus. 2017;15(4):307-17. https:// doi.org/10.2450/2017.0059-17

5. Sadana D, Pratzer A, Scher L, Saag HS, Adler N, Volpicelli FM, et al. Promoting high-value practice by reducing unnecessary transfusions with a patient blood management program. JAMA Intern Med. 2018;178(1):116-22. https://doi.org/10.1001/ jamainternmed.2017.6369

6. Bodenham A, Babu S, Bennett J, Binks R, Fee P, Fox B, et al. Association of Anaesthetists of Great Britain and Ireland: safe vascular access 2016. Anaesthesia. 2016;71(5):573-85. https://doi.org/10.1111/anae.13360

7. Patel IJ, Davidson JC, Nikolic B, Salazar GM, Schwartzberg MS, Walker TG, et al. Consensus guidelines for periprocedural management of coagulation status and hemostasis risk in percutaneous image-guided interventions. J Vasc Interv Radiol. 2012;23(6):727-36. https://doi.org/10.1016/j.jvir.2012.02.012

8. Howick J, Chalmers I, Glasziou P, Greenhalgh T, Heneghan C. Oxford Centre for Evidence-Based Medicine 2011 levels of evidence; 2011. [cited on Feb. 15, 2021]. https://www.cebm. ox.ac.uk/resources/levels-of-evidence/ocebm-levels-of-evidence

9. Bachowski G, Borge D, Brunker PAR, Eder A, Fialkow L, Fridey JL. A Compendium of Transfusion Practice Guidelines. 3rd ed. Chicago, IL, USA: American National Red Cross; 2017.

10. Kumar A, Mhaskar R, Grossman BJ, Kaufman RM, Tobian AA, Kleinman $S$, et al. Platelet transfusion: a systematic review of the clinical evidence. Transfusion. 2015;55(5):1116-27. https:// doi.org/10.1111/trf.12943

11. Cabrini L, Pappacena S, Mattioli L, Beccaria P, Colombo S, Bellomo R, et al. Administration of BP to prevent bleeding complications associated with central venous catheter insertion in patients at risk: a systematic review. $\mathrm{Br} J$ Anaesth. 2017;118(4):630-4. https://doi.org/10.1093/bja/aex060

12. ASGE Standards of Practice Committee, Ben-Menachem T, Decker GA, Early DS, Evans J, Fanelli RD, et al. Adverse events of upper Gl endoscopy. Gastrointest Endosc. 2012;76(4):70718. https://doi.org/10.1016/j.gie.2012.03.252

13. Andreyev HJ, Davidson SE, Gillespie C, Allum WH, Swarbrick E. Practice guidance on the management of acute and chronic gastrointestinal problems arising as a result of treatment for cancer. Gut. 2012;61(2):179-92. https://doi.org/10.1136/ gutjnl-2011-300563

14. Razzaghi A, Barkun AN. Platelet transfusion threshold in patients with upper gastrointestinal bleeding: a systematic review. J Clin Gastroenterol. 2012;46(6):482-6. https://doi. org/10.1097/MCG.0b013e31823d33e3

15. Tong MC, Tadros M, Vaziri H. Endoscopy in neutropenic and/or thrombocytopenic patients. World J Gastroenterol. 2015;21(46):13166-76. https://doi.org/10.3748/wjg.v21. i46.13166

16. Kheiri B, Abdalla A, Osman M, Haykal T, Chintalapati S, Cranford $J$, et al. Restrictive versus liberal red blood cell transfusion for cardiac surgery: a systematic review and meta-analysis of randomized controlled trials. J Thromb Thrombolysis. 2019;47(2):179-85. https://doi.org/10.1007/s11239-0181784-1

17. Gralnek IM, Dumonceau JM, Kuipers EJ, Lanas A, Sanders DS, Kurien $\mathrm{M}$, et al. Diagnosis and management of nonvariceal upper gastrointestinal hemorrhage: European Society of Gastrointestinal Endoscopy (ESGE) Guideline. Endoscopy. 2015;47(10):a1-46. https://doi.org/10.1055/s-0034-1393172

18. Nagata N, Sakurai T, Moriyasu S, Shimbo T, Okubo H, Watanabe $K$, et al. Impact of INR monitoring, reversal agent use, heparin bridging, and anticoagulant interruption on rebleeding and thromboembolism in acute gastrointestinal bleeding. PLoS One. 2017;12(9):e0183423. https://doi.org/10.1371/journal. pone. 0183423

19. Thomopoulos KC, Mimidis KP, Theocharis GJ, Gatopoulou AG, Kartalis GN, Nikolopoulou VN. Acute upper gastrointestinal bleeding in patients on long-term oral anticoagulation therapy: endoscopic findings, clinical management and outcome. World J Gastroenterol. 2005;11(9):1365-8. https://doi.org/10.3748/ wjg.v11.i9.1365

20. Barkun AN, Almadi M, Kuipers EJ, Laine L, Sung J, Tse F, et al. Management of nonvariceal upper gastrointestinal bleeding: guideline recommendations from the International Consensus Group. Ann Intern Med. 2019;171(11):805-22. https://doi. org/10.7326/M19-1795

21. Facciolongo N, Patelli M, Gasparini S, Agli LL, Salio M, Simonassi C, et al. Incidence of complications in bronchoscopy. Multicentre prospective study of 20,986 bronchoscopies. Monaldi Arch Chest Dis. 2009;71(1):8-14. https://doi. org/10.4081/monaldi.2009.370 
22. Kaufman RM, Djulbegovic B, Gernsheimer T, Kleinman S, Tinmouth AT, Capocelli KE, et al. Platelet transfusion: a clinical practice guideline from the AABB. Ann Intern Med. 2015;162(3):205-13. https://doi.org/10.7326/M14-1589

23. Faiz $S A$, Jimenez $C A$, Fellman BM, Huk $T$, Jazbeh $S$, Haque $S A$, et al. Incidence of bleeding complications with flexible bronchoscopy in cancer patients with thrombocytopenia. J Bronchol Interv Pulmonol. 2019;26(4):280-86. https://doi. org/10.1097/LBR.0000000000000590

24. Trajceska L, Severova-Andreevska G, Dzekova-Vidimliski P, Nikolov I, Selim G, Spasovski G, et al. Complications and risks of percutaneous renal biopsy. Open Access Maced J Med Sci. 2019;7(6):992-5. https://doi.org/10.3889/oamjms.2019.226

25. Shidham GB, Siddiqi N, Beres JA, Logan B, Nagaraja HN, Shidham $S G$, et al. Clinical risk factors associated with bleeding after native kidney biopsy. Nephrology (Carlton). 2005;10(3):30510. https://doi.org/10.1111/j.1440-1797.2005.00394.x

26. Manno C, Strippoli GF, Arnesano L, Bonifati C, Campobasso N, Gesualdo L, et al. Predictors of bleeding complications in percutaneous ultrasound-guided renal biopsy. Kidney Int. 2004;66(4):1570-7. https://doi.org/10.1111/j.15231755.2004.00922.x

27. Whittier WL, Sayeed K, Korbet SM. Clinical factors influencing the decision to transfuse after percutaneous native kidney biopsy. Clin Kidney J. 2016;9(1):102-7. https://doi.org/10.1093/ ckj/sfv128

28. Salpeter SR, Buckley JS, Chatterjee S. Impact of more restrictive blood transfusion strategies on clinical outcomes: a metaanalysis and systematic review. Am J Med. 2014;127(2):124-31. e3. https://doi.org/10.1016/j.amjmed.2013.09.017

29. Simard-Meilleur MC, Troyanov S, Roy L, Dalaire E, Brachemi S. Risk factors and timing of native kidney biopsy complications. Nephron Extra. 2014;4(1):42-9. https://doi. org/10.1159/000360087

30. Alvaro D, Caporaso N, Giannini EG, lacobellis A, Morelli M, Toniutto $\mathrm{P}$, et al. Procedure-related bleeding risk in patients with cirrhosis and severe thrombocytopenia. Eur J Clin Invest. 2021:e13508. https://doi.org/10.1111/eci.13508

31. Boyum JH, Atwell TD, Schmit GD, Poterucha JJ, Schleck $C D$, Harmsen WS, et al. Incidence and risk factors for adverse events related to image-guided liver biopsy. Mayo Clin Proc. 2016;91(3):329-35. https://doi.org/10.1016/j. mayocp.2015.11.015

32. Rockey DC, Caldwell SH, Goodman ZD, Nelson RC, Smith $A D$, American Association for the study of liver diseases. Liver biopsy. Hepatology. 2009;49(3):1017-44. https://doi. org/10.1002/hep.22742
33. Davidson JC, Rahim S, Hanks SE, Patel IJ, Tam AL, Walker TG, et al. Society of Interventional Radiology Consensus Guidelines for the Periprocedural Management of Thrombotic and Bleeding Risk in Patients Undergoing Percutaneous Image-Guided Interventions-Part I: Review of Anticoagulation Agents and Clinical Considerations: Endorsed by the Canadian Association for Interventional Radiology and the Cardiovascular and Interventional Radiological Society of Europe. J Vasc Interv Radiol. 2019;30(8):1155-67. https://doi.org/10.1016/j. jvir.2019.04.016

34. Seeff LB, Everson GT, Morgan TR, Curto TM, Lee WM, Ghany $M G$, et al. Complication rate of percutaneous liver biopsies among persons with advanced chronic liver disease in the HALT-C trial. Clin Gastroenterol Hepatol. 2010;8(10):877-83. https://doi.org/10.1016/j.cgh.2010.03.025

35. van de Weerdt EK, Peters AL, Goudswaard EJ, Binnekade $\mathrm{JM}$, van Lienden KP, Biemond $\mathrm{BJ}$, et al. The practice of platelet transfusion prior to central venous catheterization in presence of coagulopathy: a national survey among clinicians. Vox Sang. 2017;112(4):343-51. https://doi.org/10.1111/ vox. 12498

36. Müller MC, Arbous MS, Spoelstra-de Man AM, Vink R, Karakus A, Straat M, et al. Transfusion of fresh-frozen plasma in critically ill patients with a coagulopathy before invasive procedures: a randomized clinical trial (CME). Transfusion. 2015;55(1):26-35. https://doi.org/10.1111/trf.12750

37. Weigand K, Encke J, Meyer FJ, Hinkel UP, Munder M, Stremmel W, et al. Low levels of prothrombin time (INR) and platelets do not increase the risk of significant bleeding when placing central venous catheters. Med Klin. 2009;104(5):331-5. https:// doi.org/10.1007/s00063-009-1070-2

38. Abu-Sbeih H, Ali FS, Coronel E, Chen HC, Wang X, Lum P, et al. Safety of endoscopy in cancer patients with thrombocytopenia and neutropenia. Gastro Endosc. 2019;89(5):937-49.e2. https://doi.org/10.1016/j.gie.2018.12.004

39. Nandagopal L, Veeraputhiran M, Jain T, Soubani AO, Schiffer CA. Bronchoscopy can be done safely in patients with thrombocytopenia. Transfusion. 2016;56(2):344-8. https:// doi.org/10.1111/trf.13348

40. Carr IM, Koegelenberg CF, Groote-Bidlingmaier F von, Mowlana A, Silos K, Haverman T, et al. Blood loss during flexible bronchoscopy: a prospective observational study. RES. 2012;84(4):312-8. https://doi.org/10.1159/000339507

41. Chen T, Estrella M, Fine D. Predictors of kidney biopsy complication among patients with systemic lupus erythematosus. Lupus. 2012;21(8):848-54. https://doi. org/10.1177/0961203312439334 